\title{
REFUSALS TO CROSS PICKET LINES: PROTECTION OF WORKERS FROM EMPLOYER REPRISALS*
}

THE picket line is one of labor's traditional methods of implementing a strike. ${ }^{1}$ If individuals not parties to the strike refuse to cross such a line, ${ }^{2}$ the picketed employer will be unable to continue operations. But if the line is ignored by such third persons, the employer may be able to keep his business in partial operation and carry on a longer contest with the union. Because of this important effect on the outcome of labor disputes, workers not parties to strikes are strongly motivated to avoid crossing any picket line. Their refusals may spring from pure sympathy, a desire to ensure later reciprocal action by the pickets, ${ }^{3}$ or fear of physical violence, economic retaliation, or social ostracism. In any event, the policy of observing all picket lines has become one of the mores of organized labor.

* NLRB v. Rockaway News Supply Co., 197 F.2d 111 (2d Cir. 1952), ccrt. grantcd, 21 U.S.L. WeEK 3115 (U.S. Oct. 28, 1952) ; NLRB v. Illinois Bell Telephone Co., 189 F.2d 124 (7th Cir. 1951), cert. denicd, 342 U.S. 885 (1951).

1. See, generally, Gregory, Labor ANd the LAw c. 12 (1949); Lester, Economics of Labor 612, 708, 870 (1947); Peterson, Survey of Labor Econonics 617 (1947). Beginning with Thornhill v. Alabama, 310 U.S. 88 (1940), the Supreme Court went far to protect picketing as "free speech" under the First Amendment. But in recent years this trend has been severely qualified. See, e.g., Teamsters Union v. Hanke, 339 U.S. 470 (1950) ; Giboney v. Empire Storage and Ice Co., 336 U.S. 490 (1949). For full discussion, see Dodd, Picketing and Free Speech: A Dissent, 56 HARv. L. REv. 513 (1943); Teller, Picketing and Free Speech, 56 Harv. L. Rev. 180 (1942); Weinberg, Thornhill to Hanke-The Picketing Puzzle, 20 U. of CIN. L. Rev. 437 (1951) ; Note, 59 Harv. L. REv. 1123 (1946).

2. In most cases the picket line is aimed more at other workers than toward members of the general public. See Cox, The Infutence of Mr. Justice Murphy on Labor Law, 48 Mich. L. Rev. 767, 789 (1950). For the various techniques and purposes of picket lines, see Hellerstein, Picketing Legislation and the Courts, 10 N.C.L. REv. 158, 186 n.135 (1931).

3. See Hand, J., in NLRB v. Peter Cailler Kohler Swiss Chocolates Co., 130 F.2d 503, 505-6 (2d Cir. 1942). Workers refusing to cross often not only seek to insure future cooperation by the pickets, but aim more broadly at strengthening the tradition of respect for all picket lines.

4. A truck driver, for example, is subject to expulsion from his union-often resulting in loss of employment-for crossing a teamsters' picket line. Cox, The Influctuc of Mr. Justice Murphy on Labor Law, 48 MicH. L. Rev. 767, 788 (1950). And although the Taft-Hartley amendments to $\S 8(\mathrm{a})(3)$ of the NLRA, 61 STAT, 140 (1947), 29 U.S.C. § 158(a)(3) (Supp. 1951), have taken much of the sting out of loss of union membership, the union can still put substantial pressure on its members to enforce compliance with its rules.

For the social pressures involved, see Warner \& Low, The Soctar System of tul MODERN FactorX (1947).

5. "It is almost a rule of trade union ethics for one labor union to respect the picket line established by another." L. A. Young Spring \& Wire Corp., 70 N.L.R.B. 868, 874 (1946). 
Where performance of a worker's job requires him to cross the picliet line of another union, his refusal to do so may injure his employer. Should the picket line surround his own place of employment, refusal to cross would be tantamount to a sympathy strike, often leading to partial or total shut-down. And even where the line is around the plant of an employer other than the worker's own, picket-line observance may hamper the operations of his own employer by cutting off suppliers or outlets.

Whether or not employers can prevent such refusals by firing or otherwise disciplining workers ${ }^{6}$ depends upon the rights guaranteed the worlser by the National Labor Relations Act." Under Section 7 of that act. workers may engage in "concerted activities for mutual aid or protection." $\$$ Should the refusal to cross come within this provision, the employer's disciplinary action would constitute an unfair labor practice ${ }^{3}$ entitling the employee to reinstatement and lost wages. ${ }^{10}$ On the other hand, should the refusal to cross fall

Many union constitutions contain provisions forbidding their members to cross piclset lines. See, e.g., Local By-Laws, Ilinvors Unron of Telephone Workers \& 9 (rev. Sept. $11,1044)$ ( $\$ 50.00$ fine for crossing picket line without union permission). See also other union constitutions collected in Peterson, Handroor of Laros Umiors (1944).

The right of workers to honor picket lines is often incorporated in the collective bargaining agreement. U.S. Bureau of Lab. Stat. Bunl, No. 686, Union Agreenerti Pronstoms 165 (1942).

6. Employers may wish to inflict a lesser punishment than outright dismissal on the worker. The employer could demote him, as in NLRB v. Illinois Bell Telephone Co., 189 F.2d 124, cert. denied, 342 U.S. \&S5 (1951); remove accumulated seniority or pension status; or in other ways deprive the worker of important privileges.

7. 49 SтAт. 449 (1935), 29 U.S.C. $\$ 151$ (1946), as amended, 61 Sr.1T. 136 (1947), 29 U.S.C. \$ 151 (Supp. 1951).

8. "Sec. 7. Employees shall have the right to self-organization, to form, join, or assist labor organizations, to bargain collectively through representatives of their own choosing, and to engage in other concerted activities for the purpose of collective bargaining or other mutual aid or protection." 49 STAr. 452 (1935), 29 U.S.C. \& 157 (1946), as amended, 61 STAT. 140 (1947), 29 U.S.C. \$ 157 (Supp. 1951).

9. Section $S(a)(1)$ makes it an unfair labor practice for an employer to "interfere with, restrain, or coerce employees in the exercise of the rights guaranted in ssction 7." 49 STAт. 452 (1935), 29 U.S.C. $\$ 158(1)$ (1946), as amended, 61 SrAT. 140 (1947), 29 U.S.C. $\$ 158$ (a) (1) (Supp. 1951).

Strikers engaged in ordinary economic strikes, commonly referred to as "economic strikers," may not be demoted or fired for striking. But to enable the employer to licap his business going during the strike, courts have permitted him to replace the strikses permanently. NLRB v. Machay Radio \& Telegraph Co., 304 U.S. 333 (1938), 51 HARV. L. REv. 553. And the Ninth Circuit recently held that non-striling worlers may be given seniority over economic strikers. NLRB v. Potlatch Forests, Inc, 189 F.2d \&2 (9th Cir. 1951), 100 U. of PA. L. Rev. 287.

When the strike is caused or prolonged by an employer uniair labor practice, the strikers, so-called "unfair labor practice strikers," must be rehired at the end of the strike even if it is necessary to discharge replacements. E.g., NLRB v. Remington Rand, Inc., 130 F.2d 919 (2d Cir. 1942); Deena Artware, Inc., Sj N.L.R.B. 732 (1949). For discussion, see Daykin, Legalized Concerted Activities usider the Taft-Hartlcy Aet, 3 LAB. L.J. 167, 173-5 (1952).

10. See National Labor Relations Act, $\S 10(c), 49$ SrAT. 454 (1935), 29 U.S.C. $\S 160$ (c) (1946), as amended, 61 Stat. 147 (1947), 29 U.S.C. $\$ 160$ (c) (Supp. 1951). 
outside the scope of Section 7, the employer would be free to discharge or otherwise discipline the recalcitrant employee.

Workers may refuse to cross picket lines in two situations: where the picket line surrounds a worker's own place of employment; and where it surrounds the plant of another employer. A recent opinion of the Court of Appeals for the Seventh Circuit, NLRB v. Illinois Bell Telephone Co., ${ }^{11}$ suggests that in the former situation Section 7 protection will be withheld from members of an employer-recognized union who independently refuse to cross the picket lines of another union. The employer involved owned two separate plants which were each represented by a different union. ${ }^{12}$ Although he was conducting negotiations with the union in one plant, ${ }^{13}$ that building was picketed by members of the other union. ${ }^{14}$ And eight employees of the picketed plant, acting independently and without union authorization, refused to cross the picket line to their place of employment. The court held the employer justified in demoting them for their actions. Not only did the refusals fail to qualify as "concerted activity,"15 but they also lacked the requisite "mutual aid or protection." "The court treated the workers as wildcat strikers - who may be discharged or disciplined for their misconduct-on the view that their unauthorized work stoppage could impair their own bargaining agent's authority. ${ }^{17}$

The Illinois Bell case appears to be the first time the courts have specifically considered the situation of a worker who, without authorization of his recog-

11. 189 F.2d 124 (7th Cir. 1951), cert. denied, 342 U.S. 885 (1951).

12. Employees in his Chicago plant were represented by the Chicago Telephone Traffic Union (CTTU); those in the downstate plant by the Illinois Telephone Traffic Union (ITTU). Illinois Bell Telephone Co., 88 N.L.R.B. 1171, 1182-3 (1950) (intermediate report).

13. The union in the Chicago plant (CTTU) did not strike. A previous agreement between the Illinois Bell Telephone Co. and the CTTU had expired on March 29, 1947, but the parties were operating under an extension agreement while negotiating a new collective bargaining agreement. Id. at 1173 .

14. Illinois Bell's downstate employees struck and picketed both their own and the company's Chicago plant. Ibid.

15. "The record discloses unmistakably that each acted in her own individual capacity." NLRB v. Illinois Bell Telephone Co., 189 F.2d 124, 127 (1951). The court rejected as "novel" the theory that the eight employees were acting in concert with the pickets. Id. at 129.

16. The court concluded that the eight employees were not acting for their own "mutual aid or protection" since their conduct "could have only been for the benefit of those in a different bargaining unit." Ibid.

17. Id. at 128-9. For other cases denying protection to wildcat activities see NLRB v. Warner Bros., Inc., 191 F.2d 217 (9th Cir. 1951) ; NLRB v. Reynolds Pen Co., 162 F.2d 680 (7th Cir. 1947); NLRB v. Indiana Desk Co., 149 F.2d 987 (7th Cir. 1945); NLRB v. Draper Corp., 145 F.2d 199 (4th Cir. 1944); NLRB v. Brashear Freight Lines, 119 F.2d 379 (8th Cir. 1941). For discussion of the "wildcat" cases, see Notc, Availability of NLRA Remedies to Unlawful Strikers, 59 HARv. L. REv. 747, 753-5 (1946). 
nized union bargaining agent, refuses to cross picket lines around his own place of employment. ${ }^{18}$ Although protecting such unauthorized refusals would have the advantage of permitting workers to make decisions tailored to their individual needs and preferences, ${ }^{19}$ it would also have serious disadvantages. If the individual worker is allowed to make such vital decisions independently of his union, the employer will be less likely to look to the union as a responsible bargaining agent. As a result, stability of labor-management relations may be impaired. ${ }^{20}$ Furthermore, an individual may not give sufficient consideration to the serious consequences that may flow from his decision not to cross. Since in these situations virtually all workers will be faced with the problem of crossing the picket line, a relatively large number may refuse to report to their jobs. Thus there is a real likelihood of a complete or partial work stoppage causing serious injury to the employer. And such a stoppage may force other union members-even a majority-to suffer wage loss without their consent. ${ }^{21}$ Instead of relying upon individual decision, however, the union of the workers faced with crossing the picket line in most cases could call a sympathy strike. ${ }^{22}$ Should they decide to strike as a body, they would all become economic strikers-entitled to protection under Section 7. But

18. There had been one prior NLRB decision involving this fact situation. Columbia Pictures, Inc, 82 N.L.R.B. 568 (19.49). But in granting protection the Board did not specifically consider that the refusal to cross was in derogation of the order of the workers' union, or that the picket line surrounded their own place of employment. And on appeal the Ninth Circuit reversed the Board. NLRB v. Warner Bros. Pictures, Inc., et al., 191 F.2d 217 (9th Cir. 1951). The court held that this action, running counter to union orders, constituted unprotected wildcat activity.

Since the Illinois Bell case the Board, in a similar situation, granted $\$ 7$ protection to unauthorized refusals to cross. Brown \& Root, Inc, 99 N.L.R.B. No. 153 (June 27, 1952). The Board arrived at its decision without mentioning the Illisoois Bell case, which had not been argued. Communication to the YALE LAW Joumins from David P. Findling, Associate General Counsel, NLRB, dated Oct. 14, 1952, in Yale Law Library.

19. With some workers, refusal to cross involves almost a moral decision. In addition, certain employees may have a very close social relationship to the pickets.

20. For a discussion of the adverse effect of wildcat sit-down strikes capable of tying up entire plants upon other union members and upon the stability of collcctive bargaining, see Peterson, Ajuerrcan Laeor Unions 224 (1945).

21. A minority of union workers may thus, in effect, have the power of alling a strike despite the fact that most union constitutions require a two-thirds yote and other procedural safeguards before such a step can normally be talken. See note 23 infro.

22. If the pickets are employees in the same plant, a union-3uthorized sympathy strike could not be attacked as proseribed secondary pressure under $\$ \$(b)$ (4) (A) of the Taft-Hartley Act. See Santa Ana Lumber Co., \$7 N.L.R.B. 937 (1949); Di Giorgio Wine Co., 87 N.L.R.B. 720 (1949); and note 31 infro. But if the piclsets are employees of another employer, a sympathy strike to support them would be illegal secondary pressure. See Koretz, Fediral Regulation of Sccondary Strilecs and Boycofts $-A$ New Chapter, 37 Condelr L.Q. 235, 245 (1952). The situation in the Illinois Bell case seems to be a borderline question since the pickets worked in a different plant, though for the same employer. 
before calling such a strike, unions generally would carefully consider the consequences of their action and make a decision by majority vote. ${ }^{23}$

The disadvantages of individual action suggest that NLRA protection should be withheld from members of a recognized union bargaining agent who independently refuse to cross picket lines around their own employer. By treating such unauthorized refusals to cross as unprotected activities, the Illinois Bcll case would seem to limit action open to union members under such circumstances to an authorized sympathy strike. To this end the conclusion reached is desirable. The major weakness of the decision-the unduly technical interpretation of the wording of Section $7^{24}$-could have been easily avoided. There is ample precedent for denying protection on purely policy grounds even to worker activities admittedly constituting "concerted activity for mutual aid or protection."25

23. "Practically every union constitution contains some statement regarding the calling and conduct of strikes. In general, the purpose of such clauses is to minimizo hasty and ill-advised action. ... In order to call a strike the majority of unions require a two-thirds affirmative vote of the membership affected, and sanction by the international president. . . . Many stipulate that the vote shall be by secret ballot at a special mecting of the members which has been anounced a given number of days in advance, and which is attended by at least one fourth of the total membership affected." Peterson, Sunver OF LABOR ECONOMICS 555, 556 (1947).

24. The Seventh Circuit's standard of "concerted activity" is unwarrantedly restrictive. "So far as appears, the NLRB has always considered as 'concerted" any parallel activity involving more than one employee. ... Cf. United Brotherhood of Carpenters and Joiners of America, 81 N.L.R.B. 802, 818 (1949)." Koretz, Federal Regulation of Sccondary Strikes and Boycotts-A New Chapter, 37 CoRnell L.Q. 235, 250 n.74 (1952). Sec also NLRB v. Phoenix Mutual Life Insurance Co., 167 F.2d 983 (7th Cir. 1948) (two salesmen complaining to their employer concerning the selection of a new cashier; held: engaged in concerted activity). Even where one worker refused to cross a picket line, other courts have found him to be in "concert" with the pickets. Cyril de Cordova, 91 N.L.R.B. 1121 (1950) (single employee refusing to cross picket line against another employer).

In limiting employees' "mutual aid or protection" to specific demands for improvement of their own working conditions, the court's view of labor benefits is unrealistically narrow. Employees frequently gain from strike victories of other workers. Improved conditions for one group of workers may facilitate improvement for others, particularly in closely related employment. See NLRB.v. Peter Cailler Kohler Swiss Chocolates Co., 130 F.2d 503, 505-6 (2d Cir. 1942); Cyril de Cordova, 91 N.L.R.B. 1121, 1135 (1950); Peterson, Survey of Labor Economics 296 (1947). A main producer often sets the pace for the wages of the entire industry. Harrison \& Dubin, PATtERns OF UNIONManagensent Relations 182-3 (1947).

25. Thus protection has been denied to union unfair labor practices, Rawleigh Co, 90 N.L.R.B. 1924, 1927 (1950); to violations of federal law, Southern S.S. Co. v. NLRB 316 U.S. 31 (1942); American News Co., 55 N.L.R.B. 1302 (1944); to breaches of contract, NLRB v. Sands Mfg. Co., 306 U.S. 332 (1939); and to various other types of disfavored worker conduct, United Auto Workers of America, AFL v. Wisconson E.R. Bd., 336 U.S. 245 (1949) ("quickie" strike); NLRB v. Fansteel Metallurgical Corp., 306 U.S. 240 (1939) (sit-down strike) ; Elk Lumber Co., 91 N.L.R.B. 333 (1950) (slowdown); Massey Gin \& Machine Works, Inc., 78 N.L.R.B. 189 (1948) (partial strike). 
But the same reasoning will not justify denying protection to similar action by workers not members of a recognized union bargaining agent. Uinder such circumstances, the courts have consistently protected workers refusing to cross. ${ }^{26}$ Although their conduct might be open to the same objection of potentially serious injury to the employer and other employees, it would in no way be wildcat activity in derogation of the authority of any bargaining representative. And since such employees are not represented by a union of their own choosing, they have no effective alternative method of expressing support of the pickets. So refusal to protect individual action would deprive them of all action.

Where a picket line surrounded the plant of an employer other than the worker's own, a recent opinion of the Court of Appeals for the Second Circuit, NLRB v. Rockaz'ay New's Supply Co., ${ }^{27}$ denied protection under Seetiun 7 . A deliveryman had been fired for refusing to cross a picket line around a plant at which he was required to pick up newspapers. Although conceding that a refusal to cross a picket line under such circumstances was a "concerted activity for mutual aid or protection" within the meaning of Section 7,23 the court denied protection for what it considered overriding policy considerations. With Judge Clark dissenting, the majority opinion declared that the worker's right to refuse to cross must be subordinated to his own employer's right to set reasonable working rules. ${ }^{29}$

Judge Clark's dissenting view, that the refusal to cross should be protected 00 in this situation, seems more persuasive in terms both of congressional intent and underlying policy considerations. In making secondary boycotts union unfair labor practices, ${ }^{31}$ Congress specifically exempted a refusal by any

For general analysis of protected and unprotected concerted activities, see Co:, The Right to Engage in Concerted Activities, 26 Inn. L.J. 319 (1951); Petro, Concerted Activities-Protected and Unprotected, 2 LAB. L.J. 3 (1951); Note, Azailability of NLR.A Remedies to "Unlawful" Strikers, 59 HaRv. L. REv. 747 (1946).

26. NLRB v. Miontag Bros. 140 F.2d 730 (5th Cir. 1944); Carter Carburetor Corp. v. NLRB, 140 F.2d 714 (8th Cir. 1944); West Coast Casket Co., 97 N.L.R.B. No. 103 (Dec. 29, 1951); New York Tel. Co., S9 N.L.R.B. 383 (1950).

27. 197 F.2d 111 (2d Cir. 1952), ccrt. grantcd, 21 U.S.L. Werk 3115 (Oct. 23, 1952). Contra: Cyril de Cordova, 91 N.L.R.B. 1121 (1950).

28. NLRB v. Rockaway News Supply Co., 197 F.2d 111, 113 (2d Cir. 1952).

29. Ibid.

30. "[W] hen [Congress] limited the weapon of the boycott it took pains to except from the newly defined unfair labor practices of a union or its agents the crossing of a picket line .... When, therefore, the Board acts in what seems to me the intended spirit of this specific $\$ 8$ (b) (4) exception to hold that 3 union membar doss not lose the statutory protection...., I do not see how we can rule that action erroncous as a matter of law." Clark, J., dissenting in NLRB v. Rochaway News Supply Co., 197 F.2d 111, 115-6 (2d Cir. 1952).

31. The category of union unfair labor practices was created by the Tait-Hartley Act. Secondary pressures by unions are proscribed by $\$ \$(b)(4)$ (A), which maltes it an unfair labor practice for them "to engage in . . . a strike or a concerted reiusal in the course of their employment to use, manufacture process, transport or otherwise handle 
person to cross a picket line around an employer (other than his own). ${ }^{\mathrm{j} 2}$ Thus Taft-Hartley distinguishes between refusals to cross picket lines around the worker's own employer and around another employer. Only the latter type of refusal is exempt from a union unfair labor practice charge. ${ }^{3 a}$ Although not conclusive of protection under Section 7 , the express exemption scems indicative of a desire to provide such protection.

or work on any goods, articles, materials, or commodities or to perform any services where an object thereof is: (A) forcing or requiring . . . any employer or other person to cease using, selling, handling, transporting, or otherwise dealing in the products of any other producer, processor, or manufacturer, or to cease doing business with any other person ...." 61 Stat. 141 (1947), 29 U.S.C. $\$ 158$ (b) (4) (A) (Supp. 1951). The legislative history of this section may be found in NLRB, LEGISLATIVE HISTORY OF THE Labor Management Relations Act, 1947 (1948). For interpretations of the cases decided under this section, see Johns, Picketing and Secondary Boycotts Under the TaftHartley Act, 2 LAB. L.J. 257 (1951); Developments in the Laze-The Taft-Harllcy Act, 64 HARv. L. Rev. 781, 798 (1951).

32. "Provided, That nothing contained in this subsection (b) shall be construed to make unlawful a refusal by any person to enter upon the premises of any cmploycr (other than his own employer), if the employees of such employer are engaged in a strike ratified or approved by a representative of such employees whom such employcr is required to recognize under this Act . . ." 61 STAT. 142 (1947), 29 U.S.C. $\& 158$ (b) (Supp. 1951). For a discussion of the Proviso, see VAN ARKen, AN ANalysis of tue Labor Manageanent Relations Act 1947, p. 52 (1947); Petro, The Enlightening Proviso, 1 LaB. L.J. 1075 (1950); Tower, The Puzaling Proviso, 1 LAB. L.J. 1019 (1950); SEN. REp. No. 105, 80th Cong., 1st Sess. 23 (1947).

The wording of the proviso poses several problems which, to date, have remained un solved. The proviso requires approval by an employee representative whom the employcr must recognize. In most cases this will mean the existence of a certified union. Employer recognition (and Board certification) hinges on the existence of a union majority. This in turn may depend on the appropriate collective bargaining unit to be considered. The proviso does not make clear whether the union must bear the risk of these determinations or whether a reasonable belief of the existence of a union majority will suffice.

Under a strict reading of the proviso it would seem to make no difference whether the picket line is legal or illegal so long as it has the approval of a proper employce representative. Thus in some circumstances workers honoring illegal picket lines may bo protected under the proviso. On the other hand, a primary recognitional picket line is legal under the Taft-Hartley Act, even though there is no recognized union majority. See SeN. Rep. No. 105, 80th Cong., 1st Sess. (1947). Workers refusing to cross such a legal picket line would seem to be unprotected by the proviso.

Furthermore, the proviso inexplicably safeguards "persons," which includes workers as well as unions. 49 STAT. 450 (1935), 29 U.S.C. 152(1) (1946). Thus it seems to protect more than is prohibited by $\S 8(\mathrm{~b})$, since that section is applicable only to acts of a union or its agents. One explanation for the use of "person" rather than "union" is that the draftsmen were here thinking only of the individual as an agent of the union. Van Arked, An Analysis of tee Labor Manageasent Relations Act, 1947, p. 52 (1947).

33. Even where the picket line surrounds one's own place of employment, refusal to cross may, in some cases, constitute a proscribed secondary activity. See note 22 supra. So it cannot be argued that inclusion in the proviso of refusals to cross lines around one's own employer would have provided useless protection. 
The policy reasons militating against protecting some independent refusals by workers to cross picket lines to their own place of employment ${ }^{21}$ are nut generally applicable where the lines surround another employer. Cnder most circumstances, granting protection in the latter situation will not too seriutsly injure the worker's own employer or his fellow workers. For, unlike the picket line around the worker's own plant, only a limited number of workers are faced with the decision of whether or not to cross. Thus, a serious worl: stoppage is unlikely. Also, where the picket line surrounds a plant other than the worker's own, his union could not strike to back up his refusal to cross. In the view of the Second Circuit, such a strike would constitute a proseribed secondary boycott. ${ }^{35}$ Since the denial of Section 7 protection under these circumstances will thus result in a complete withdrawal of the right to refuse to cross picket lines-a right which Congress apparently did not intend to withdraw when it banned secondary pressures-protected independent action is the only way this right can be exercised.

But even protection under Section 7 is inadequate for the worker forced to make such an isolated decision. Although with such protection the employee could not be fired directly for refusing to cross, the employer could force him either to obey an order to cross or to remain out of work altogether as an economic striker. ${ }^{36}$ If the worker were to go on such an independent strike, the employer could permanently replace him. ${ }^{37}$ The rest of the union would be unable to participate in the strike because of its secondary nature. ${ }^{39}$ And since only a few workers would ordinarily be striking, the usual impracticability of replacement would not be a deterrent. So the employer, merely by observing the proper formalities, would be able to negative the worker's right of refusal. ${ }^{39}$ Under these circumstances, the court should graft an exception to the employer's normal right of permanent replacement so as to permit only temporary replacement of employees refusing to cross picket lines around plants other than their own." The limited number of workers generally in-

34. See page 95 supra.

35. See NLRB v. Rockaway News Supply Co., 197 F.2d 111, 114 (2d Cir. 1952).

36. See Rockaway News Supply Co., 95 N.L.R.B. 336, 337 (1951); Cyril de Cordowa, 91 N.L.R.B. 1121 1137-S (1950) ; Pinaud, Inc., 51 N.L.R.B. 235, 236 (1943).

37. See note 9 supra. To effectuate such "permanent replacement," the employer is merely required to hire a substitute before dismissing the striling worlier. See, c.g., Celanese Corp. of America, 95 N.L.R.B. 664, 669 (1951).

38. See NLRB v. Rockaway News Supply Co., 197 F.2d 111, 114 (2d Cir. 1952). The possibility of union support might deter the employer from firing the realcitrant employee. The absence of this deterrent strengthens the power of the employer.

39. Retrospectively, it is sometimes difficult for the Board to determine whether, in a particular case, replacement actually preceded dismissal. Such difficulties stem mainly from the employer's ignorance of his rights. But an employer, aware of the proper procedures to be followed, would have no difficulty in officially replasing an employee before firing him.

40. At present, only employees striling because of an employer unfair labor practice are given such treatment. In those cases the Board often exercises its discretion under 
volved would prevent such a requirement from offering too serious an obstacle to the employer in maintaining operations. And the temporary loss of wages would be a deterrent to rash action by the individual worker.

$\S 10$ (c) of the NLRA to award the strikers back pay for time lost during the strike. Under the instant proposal, however, employees choosing to strike individually rather than cross picket lines would lose their pay while on strike. 